\title{
Thinking on the withdrawal mechanism of venture capital in China
}

\author{
YU Cheng-xuan \\ (Wuhan University of Technology, Wuhan 430070, China)
}

\begin{abstract}
From the operating mechanism of venture capital, we can see that, the withdrawal mechanism of the venture capital plays a decisive role in the ultimate success or failure of the venture capital. One of the key issues affecting the development of China's venture capital industry is that the withdrawal mechanism is not sound. In referring to the foreign successful experience, we must fully analyze it by integrating with the actual situations of China. Currently, the capital market, property market, venture capital system and legal system of China are not perfect, and the improvement of the mechanism can not be done overnight. We can first choose to withdraw in a practical way in the current stage to gain the time to develop, and then continue to pave the way to create conditions, and finally establish a perfect venture capital withdrawal mechanism.
\end{abstract}

Key words: venture capital; withdrawal mechanism; China

\section{Introduction}

Venture capital is an investment method which is popular worldwide. And its definitions by the international authoritative institutions are as follows: as defined by National Venture Capital Association (NVCA), venture capital is a kind of equity capital which is invested into the emerging enterprises (especially the SMEs) which develop rapidly and have great competition potential by professional financiers; By contrast, the definition by Organization for Economic Cooperation and Development (OECD) is wider, i.e., all investment based on hi-tech and knowledge and in innovative products or services with intensive production and management technologies can be seen as venture capital. From the perspective of investment behavior, venture capital is a process of investing capital into the field of hi-tech research and development bearing the risk of failure. From the perspective of operation mode, it refers to the process in which the investment intermediaries managed by the professionals invest venture capital into potential high-tech enterprises, and it is also an investment mechanism for coordinating the relation among the venture capital investors, technicians and the investors, and sharing interest and risks.

\section{The withdrawal mechanism from the operating mechanism of venture capital}

\subsection{The operation of venture capital}

The operation of venture capital mainly involves investors, intermediaries (venture capital companies) and investment objects (venture enterprises) which play their own roles in the operation of venture capital.

Investors are providers of venture capital. They can be established with government investment, enterprise investment, non-governmental privately-held capital, capital self-raised by the scientific research units, commercial bank loan and foreign investment, etc.

YU Cheng-xuan, Ph.D. candidate, Wuhan University of Technology; research field: theory of investment. 
Venture enterprises are the receivers of venture capital. They posses the hi-tech ideas or achievements, but lack the capital of industrializing the achievements. Once getting the capital support of the venture capital institutions, they industrialize the achievements, and obtain the economic return of technical innovation and achievement industrialization through the operation of the market mechanism.

Venture capital companies are the "bridge" of communicating the venture enterprises and the investors. They raise capital from the society one and one hand, and invest the capital to the venture enterprises with different strategies after strict investigation and screening, and actively participate in the operation management of the venture enterprises. When the right time comes, they withdraw the capital with added value from the venture enterprises in appropriate ways, so as to realize the rolling appreciation of the venture capital.

\subsection{The key for the venture capital-the withdrawal mechanism}

By analyzing the whole operation process of venture capital, we are clear that, the key for the venture capital to produce circulatory profit is the withdrawal mechanism of venture capital. If the link is lacked, the chain of the venture capital activities will be interrupted, the venture capital cannot realize investment appreciation and virtuous cycle, and cannot attract the social capital to join the rank of venture capital. Specially, the significance of the venture capital withdrawal mechanism can be mainly reflected in the followings: First, the withdrawal method of the venture capital is also a way of realizing profit. The venture capital and the investment in the general capital market have different methods of gaining profit. The investment of the general capital market mainly gains the profit by dividend payout and share appreciation, and the venture capital generally does not aim at enterprise dividend, but only takes share appreciation as the reward, necessarily requires a liquidation method capable of creating substantial capital appreciation, and thereby depending on a withdrawal channel capable of smoothly withdrawing. Second, the most fundamental characteristic of venture capital not only lies in the capital that is invested into products or fields with an uncertain future riskily, but also in the circulatory liquidity of capital and investment activities. Once got success, the investors can withdraw with high profit and have a new round of investment, which more require the venture capital to be withdrawn. Again, the venture capital withdrawal mechanism provides an objective evaluation method for the venture capital activities. The objects of the venture capital are the emerging enterprises with great development potential. Such enterprises are the comprehensive integration of new ideas, new technologies, new products and new markets. Their value cannot be determined by simple financial accounting, but only be found and realized by market evaluation. And the best standard for evaluating the investment value is to see if the venture capital is appreciated greatly when withdrawing.

Another issue highlighting the significance of the venture capital withdrawal mechanism is that, because the venture capital enterprises have inherent high risks, the venture capital programs are easier to fail comparing with the non-venture capital programs. Venture enterprises are difficult to keep rapid growth for a long time. To gain the highest return, the venture capital must withdraw before the rapid growth of the invested enterprises is over, so as to gain capital profit. Once the venture capital programs fail, not only the capital is not appreciated, and capital will be also difficult to be recovered. Therefore, a convenient and smooth withdrawal mechanism will help the venture capital to minimize the loss.

Clearly, venture capital and its withdrawal mechanism are inalienable. The high risk of the venture capital usually means high profit, and the key for obtaining profit and transferring risks is the withdrawal link. Withdrawal is a channel of gaining profit from venture capital, and it is the unique channel. Successful withdrawal not only means high return, but also is the basis for a new round of venture capital. Therefore, in order to develop 
venture capital, we must establish the sound withdrawal mechanism, so as to attract more capital to have venture investment.

\section{Foreign venture capital withdrawal mechanism}

From the foreign venture capital development modes, they mainly can be summed up as the Japan-Germany mode, with banks as the center, and the American mode, with the security market as the center. The venture capital systems of Japan and Germany take the banks as the center, and the venture enterprises are used to seeking capital sources from the investment companies and the banks belonging to groups. It is generally believed that, it is the best harvesting method of the venture capital if the enterprises issue shares to the public, because the withdrawal mechanism of the share issuance of the enterprises determines an implicit contract on the structure with the control right to the future enterprises between the capital suppliers and users. The implicit contract is effective to the interest conflict between the client and the agent under high-risk condition. Only to take the enterprise share issuance as the potential main withdrawal mechanism in a small cap stock market, a certain scale is realistic. In the Japan-Germany mode with large companies and large banks as the investors, the market structure is based on large enterprises and enterprise groups, and it is rather difficult if the venture enterprises want to meet the standards of the OTC market. Lacking an active small cap stock market with a certain scale, the withdrawal of the venture capital is mainly based on enterprise merger and share repurchasing, and the lacking of an incentive mechanism to the entrepreneurs restrains the development of the venture capital market to some degree.

The main experience for America to be succeed in venture capital lies in that its developed multi-level capital market and property market provide a multi-channel withdrawal method. America's withdrawal methods are classified into three types, i.e., public listing, sale and asset liquidation. Also, some scholars classify them into four categories (CHENG, 1999) or six categories (CHENG, et al., 2000), and such categories are only the sub-division of the three types, so they do not have any substantial difference, thereby not affecting the research on relevant issues.

\subsection{Public listing refers to IPO}

IPO is usually the best withdrawal method of venture capital. IPO can converts the non-negotiable shares held by the venture capitalists into stocks of listed companies, to realize profit and liquidity, and the method can commonly gain quite high profit. IPO is a kind of confirmation of the financial market to the production achievements of the company, and the method keeps the independency of the company, and it is good for building the enterprise image and keeping sustainable financing channel. In America, about 30\% venture capital adopts the withdrawal method. But the public offering and listing need the cooperation of the market environment and quite high access conditions, and the withdrawal cost is quite high. In addition, because the enterprise investment fund is considered as the insider, the held shares are strictly limited by Clause 144A of United States Securities and Exchange Commission, and only a small number of shares of the fund can be transferred after IPO, while other shares can be gradually transferred after a few years. Because the listing standard of the main-board market is quite high, the regulation is strict, the venture enterprises are generally medium-sized and small-sized hi-tech enterprises, and they are difficult to meet the requirements in continuous operation history, net assets, profit, etc., so it is usually very difficult to list in the main-board market. Therefore, many countries establish second-board market specially serving the hi-tech enterprises and venture capital, e.g., America's NASDAQ market, growth 
enterprise market of Canada Vancouver Stock Exchange, Belgium EASDAQ Market and Britain's AIM market. Compared with that in the main-board market, listing in the second-board market is a little easier, the listing scale is smaller, and mainly offers financing service to emerging SMEs and venture capital enterprises with growing potential, which enhance the attraction of withdrawing the investment through IPO.

\subsection{Sale}

Sale includes two forms, i.e., sale and equity repurchasing. Sale is divided into general acquisition and second phase of acquisition. Although IPO is the gold harvesting method of venture capital, because the venture capital supports a large number of enterprises and the market capacity is limited, various drawbacks also exist in public listing, so it is not the withdrawal method mostly used in practice. In fact, the sale method always occupies an absolutely important position in America's venture capital history, in particular when the stock market is not in good conditions. In recent years, withdraw through the sale method accounts for larger and larger part in the rapidly developing venture capital. Statistics show that, as for the withdrawal method, general acquisition accounts for $23 \%$, the second phase of acquisition accounts for $9 \%$, stock repurchasing accounts for $6 \%$, and the third accounts for a total of 38\%, which is larger than the IPO part (WANG, 2008). In 1990s, the fifth merger wave arose in America, the merger and acquisition amount in every year is up to 300 billion US dollars, and the acquisition and merger market provides broad space for the venture capitalists to smoothly sell their equity. General acquisition mainly refers to the acquisition and merger among the companies. Because the buyers do not need to pay cash, it is easy to attract them, and the transaction is very flexible. But the profit is lower than that of public listing, and the venture companies cannot maintain their independence after being acquired by a large company and the management of the companies is affected.

The second phase of acquisition means a venture capital company transfers the equity of the venture enterprise to another venture capital company, and hands over the second phase of investment to it. If the original venture capital company only sells partial equity, part of the original investment flows, and forms the investment portfolio with the new investment. If the equipment is fully transferred, the original venture capital company fully withdraws. But the venture capital is not withdrawn from the venture enterprise, what is converted is only different venture capital investors, so the enterprise is not impacted by the investment withdrawal.

Equity repurchasing means a venture enterprise repurchases the equity of the company to the venture capital fund with cash. The venture capital can get the cash (or negotiable securities) but not only a kind of equity, and can quickly withdraw from the venture enterprise. In addition, equity repurchasing only involves the parties of the venture enterprise and venture capital, so the property relation is clear and the operation is easy. Furthermore, the external equity can be fully converted into internal equity, so that the venture enterprise keeps full independence, and possesses enough capital to preserve and increase the value.

\subsection{Liquidation or bankruptcy}

It is a withdrawal method which is used when the venture enterprise is not expected to gain high profit in the future. According to the statistics, among American enterprise which are supported by venture capital, $20 \%$ to $30 \%$ fully fail, about $60 \%$ are frustrated, and only $5 \%$ to $10 \%$ venture enterprises can succeed. In America, about $32 \%$ venture capital is withdrawn through this method. This method usually can recover $64 \%$ of the original investment (FAN, SHEN \& CHEN, 2009). But if necessary, we must implement decisively. Otherwise, more losses will be brought, because the operation status of the enterprises may continuously go worse, and the capital invested into bad enterprises has a certain opportunity cost. Better that the capital is recovered in time and invested into more hopeful programs than that the original investment cannot play any active role. 
From the adoption proportion of the withdrawal methods, we can see that, according to the survey on America's 442 venture capital programs, among the venture capital withdrawal methods, 30\% venture capital is withdrawn through IPO, 23\% through merger and acquisition, 6\% through enterprise share repurchasing, 9\% through share reselling, $6 \%$ through loss liquidity and $26 \%$ through share cancellation because of loss.

\section{China's venture capital withdrawal mechanism}

From some perspective, China’s venture capital really developed after MJZY “Proposal No.1” in 1998. According to the statistics by Institute of China Science and Technology Finance, by September 2003, there had been a total of 92 venture capital enterprises in the whole country, and 7.4 billion yuan capital. And by the end of 2008, as reported by a Chinese news agency reporter in 2001 Chengdu Western Investment Forum, China had had nearly 200 venture capital companies, and the total invested capital had exceeded RMB30 billion yuan. It is clear that venture capital develops very rapidly. But we also see that, the venture capital of China is still in the initial stage. Data analysis shows that only fewer than $15 \%$ of more than 20,000 hi-tech achievements of provincial and ministerial levels or above can be really converted. Among the scientific and technological achievements which have been converted, capital self-raising accounts for $56 \%$, national loan accounts for $26.8 \%$, and venture capital only accounts for $2.3 \%$. That shows that China's venture capital has not assumed the right responsibilities. And one of the key issues affecting China's venture capital industry development is that the withdrawal mechanism is not sound, and the withdrawal channel is not smooth. From the above international comparison, in establishing the venture capital withdrawal mechanism of China, we must refer to the foreign experience, in particular the America's successful experience. However, the emerging of the venture capital must depend on the national situations and restraining conditions of China, so venture capital is also restrained and limited by such conditions. Therefore, we must establish the withdrawal mode suitable for China's economic operation mechanism in exploration based on the current situations of China.

\subsection{IPO}

\subsubsection{From the main-board market}

The main-board market with too high an assess threshold, has strict regulations on the listed companies in history, scale, achievement, industry, etc., so that medium-sized and small-sized enterprises are difficult to meet the conditions. Therefore, the venture capital withdrawn through the main-board market is unlikely. The B-share market shall be an ideal withdrawal method for foreign investment. But because of the positioning, the B-share market has many defects and development obstacles. The biggest obstacle for the foreign investment to enter the domestic venture capital field is the openness of the financial market, RMB cannot be freely exchanged, and the exchange rate risk exists. Even if the foreign investment wants to enter the venture capital field, the issue of withdrawing also blocks the investment. In addition, the B-share market also has problems that the listed companies have small common cap, poor performance and high transaction expenses, and the information disclosure needs to be improved, the risks are high, etc., which affects the foreign investment to enter the venture capital field.

\subsubsection{From the second-board market}

In the mentioned nine withdrawal methods, it is expected that the venture capital experts of China will withdraw at most through the second-board market, which is the best method (up to 21\%). In the country, many scholars also think we shall open up the second-board market. But I think it is not realistic for the current China to 
realize venture capital through the second-board market, that because:

(1) The growth and development of the second-board market objectively depends on the conditions and the environment of its growth and development, in particular, the standard degree of the securities market and the development degree of the hi-tech industry and venture capital.

First, from the development degree of the hi-tech industry and venture capital: The prosperity of America's NASDAQ market mainly thanks to the highly developed IT industry and the perfect venture capital system. And currently, the conversion rate of scientific and technological achievements of China is low, and the hi-tech industry capital investment is low. Also, the venture capital system is very incomplete. According to the 1998 world's international competitiveness evaluation, the market law supporting to the technical development and application research of China ranked the world's No. 20, the new enterprise startup easiness ranked No. 28, the anti-monopoly competition policy evaluation ranked No. 36, the university and enterprise cooperation ranked No. 20, the scientific research achievement industrialization ranked No. 37, the new technology adoption and absorption ranked No. 46, and the intellectual property protection ranked No. 42. This relatively weak environment is clearly not good for the growth of the second board market. Second, from the standard degree of the securities market, the current main-board market of China has many problems, e.g., few institution investors, many medium-sized and small-sized investors, poor anti-risk capability, low transparency of the securities market, low standard degree of the listed companies, severe speculation, frequent illegal activities and immature regulation means. A basic open, fair and just environment has not been formed, and the legal right and interest of the medium-sized and small-sized investors are not protected. Under such circumstance, to open up the second-board market will add the difficulty in market regulation and the risks of the investors. Again, it still remains to be studied that the single second-board market is reasonable or not in structure. The scale of a single growth enterprise market may be not enough. America's NASDAQ market also consists of the national market, small-sized capital market and over-the-counter market. Therefore, China's venture capital system, capital market and hi-tech industry have not been well developed, particularly the securities market is not standard enough, and so rushing to open up the second-board market will bring high risks.

(2) The second-board market of China cannot be developed overnight. Even if in America, from 1946 when ARD was established, to 1971 when NASDAQ was formally opened, 25 years was experienced. The discussion about the second-board market of China has been lasted for long. The second-board market was almost certain, but until now, it has not been opened up which also proves that the conditions for its open-up have not been fully mature.

(3) Even if the second-board market is opened up, its way to become mature still needs quite a long time. In a short time, the market capacity and the expanded scale won't be too large, which absolutely cannot fully meet the listing requirements of many venture capital enterprises.

(4) On the overseas second-board market, after years of brilliance, America's NASDAQ market becomes more and more unstable. All main securities markets of Europe ever set up the second-board market based on the main-board market in the 1980s, but failed one by one; Japan, Korea and Hong Kong also put forward the second-board market, but the effect was not very ideal. This issue is worth our serious consideration. Moreover, the Mainland of China is still in a far distance from such countries or areas with very developed market economy.

Therefore, it is unlikely to withdraw the venture capital through the second-board market in the current stage. I am not denying the role of the second-board market, but only think to establish the second-board market of China after standardizing the operation mode of the main-board market and establishing quite reasonable and 
mature legal system, so that the venture capital can be withdrawn through the listing and issuance of the second-board market. After all, as an effective venture capital withdrawal method, the second-board market has its irreplaceable advantages. Vice Chairman CHENG Si-wei of China pointed out at the "2001 China (Hunan) Hi-tech Industry Development and Venture Capital International Forum” that, now the establishment of the growth enterprise market still has the problems of legislation and legal procedures as well as risk prevention and establish timing. So it still needs a period of time to establish the independent second-board market. That's the analysis based on the basic conditions of China.

Nevertheless, IPO, such an internationally recognized gold withdrawal method, is not bad in the current realistic conditions of China, and can be changed indirectly according to the realistic situations.

\subsubsection{Utilize the "shell" resource}

In view of the above analysis, the venture capital investors can make some modifications to IPO and gain profit with the "shell resources", and I think that is quite a practical venture capital withdrawal method currently. $14 \%$ experts select RTO. The venture capital investors can obtain the control right and dominating right to some "shell" listed companies in advance. Once the enterprises which receive the venture capital become mature, they can inject or transfer the invested venture capital or more capital into the "shell" listed companies, so as to complete the return and appreciation of venture capital, i.e., RTO. This method is currently quite common, and the main listing and financing method adopted by the domestic hi-tech venture enterprises in the domestic securities market, e.g., typical cases like the "Sichuan Changzheng" acquisition by "TOP software" and the "Acheng Iron and Steel” acquisition by "Clever”. In addition, many hi-tech enterprises obtain the shares of the listed companies by exchanging equity with them or directly injecting assets and programs to them to get their shares, so as to realize backdoor listing, and realize the capital realization and value adding by reorganizing the listed companies, operating the second-board market, increasing shares and financing. Such approach can be a choice for the realization and the withdrawal of the venture capital in the status quo that China's current "shell" resources are relatively lacked. Even in the future, when China has its own second-board market, the listed resources will be not possible to be fully released in a short time, so that the "shell resources" will still have their own value of existing. In addition, this approach also saves many complicated procedures for listing application and the corresponding cost.

\subsubsection{Overseas listing}

We can select the overseas venture capital withdrawal channel, i.e., to be listed in the overseas growth enterprise market. For venture capital, what is important is to effectively withdraw the capital, and that withdrawal market is not important. In addition, many foreign markets hold an active and welcoming attitude to the listing of the companies of other countries. The venture capital of China can be directly listed in NASDAQ, Vancouver growth enterprise market and Hong Kong growth enterprise market, or shell listed in the overseas market. The venture capital of Israel and some European countries is always withdrawn with the America's NASDAQ market. Now China have very few enterprises which meet the U.S. NASDAQ listing requirements, but we can fully make some of the growth enterprise market of some countries and areas around, e.g., the withdrawal of the venture capital in the growth enterprise markets in Singapore, Korea, Hong Kong, etc.

\subsection{Sale}

A total of 38\% experts select enterprise acquisition and merger, repurchasing and the second phase of acquisition, i.e., the sale method, and the total number exceeds the proportion of selecting to withdraw through the second-board market. That well fits the America's actual situations. But the author believes that although it has 
many advantages, the execution of the sale method in China still has a lot of obstacles, because:

(1) The property right of the venture enterprises is unclear. In the property right trading market, what the venture enterprises are selling is mainly their equity. So the property right problem must be solved if we want to withdraw the venture capital through the sale of the enterprises. In China, many hi-tech enterprises grow out of universities, research institutes or traditional enterprises, and their property right relation with the original units is vague, even for typical venture enterprises. For lacking appropriate legal and social bases, they can only be forced to apply the traditional mode of classifying enterprises implemented in the planned economy period, i.e., determine the types of the enterprises by the administrative relation and the nature of ownership, but cannot determine the right and obligations between the entrepreneurs and between the entrepreneurs and the investors with contract based on laws, so that the property right of them is unclear just like many SMEs. That is the root cause for the existence of the property right problem of the venture enterprises.

(2) The property right evaluation agencies and property right trading market are undeveloped. The enterprise property right trading of China is mainly completed in local securities trading markets. Such local securities markets are established by all local governments, and the original intention of the establishment is to substitute the functions of the governments, make an inventory of assets based on the markets and promote the economic structural adjustment. But because the operation of the property right trading agencies neither has any legal basis nor has any experience for reference, so that the development of the property right trading agencies is in a stagnant state, and have many problems, e.g., the property right trading is not marketized, and usually the property right sellers register and list in the property right trading agencies, and non-transferees or transferees seldom. Most property right trading agencies belong to different local administrative departments, and encounter strong resistance from other administrative departments in actual property right trading. Always, they promote the establishment of agreements of both parties with the help of the administrative power, and the management has low quality, most trading agencies are government officers or will become government officers without market pressure and innovation initiative. With regard to this, the government issued the "Notice on Clearing up and Rectifying the OTC Illegal Stock Market by Securities Regulatory Commission Forwarded by General Office of the State Council” in April 1998, and ordered to close the regional property right trading markets in principle. Under such circumstance, many SMEs can no longer carry out property right trading, so the approach for the venture enterprises to try to sell their equity through the property right trading markets, and withdraw is also cut off.

(3) The laws are incomplete. Now there is no law special for regulating the venture capital, and the Company Law and Securities Law related to the venture capital also have some clauses not good for establishing the venture capital system. For example, according to Articles 22 and Articles 35 of the Company Law, shareholders of limited liability companies must not freely transfer the contribution, which blocks the withdrawal of the venture capital. According to Article 147 of the Company Law, the initiators who hold the shares of the holding limited companies must not transfer their shares within three years from the establishment date of the company, which also blocks the venture capital withdrawal. According to Article 149 of the Company Law, the company must not repurchase its stocks, which resists the management repurchasing approach withdrawal. And the regulation in the Securities Law that the legal person shares cannot be circulated is also a realistic obstacle.

Therefore, we shall vigorously promote the sale approach, establish enterprises with clear property right in strict compliance with the requirements of the modern enterprise system at the very beginning of the establishment of the venture enterprises, to prevent problems brought by unclear property right from the very 
beginning on the one hand, and improve the enterprise property right trading market and establish the property right evaluation agencies on the other hand. To close the regional equity trading markets is not the best choice, and we shall establish and gradually open the national equity trading market for the SME financing service after clearing up and rectifying them, develop their most strong points, and remove the adverse impact. Meanwhile, it is necessary to establish the Venture Capital Law as soon as possible, and amend some existing laws.

\subsection{Utilize the OTC market}

The author believes another feasible withdrawal approach is to establish the OTC market, and 10\% experts also make such a choice. OTC is the initial state of the development of the capital market. Before establishing a centralized securities exchange, the property right trading of most enterprises is realized by OTC. The OTC has the advantages that it is very flexible, has not listing standard, does not need strict trading regulation, provides an exchange and information communication channel for the investors and the venture enterprises, promotes the venture capital to replace industrial capital, and can effectively prevent financial risks because of its small scale. Therefore, now most securities exchanges of all countries keep such trading approach. The biggest problem of the OTC is that it cannot form a unified price, the traders look for quite high price and have quite high negotiation cost, and the market efficiency is far lower than that of the trading in the exchanges.

Looking at the current market conditions in China, there is nearly no any OTC market. Even if the scale is quite small and very irregular, it is still a property right trading approach quite suitable for the development status of China's venture capital. We can consider to setting up the OTC of the venture capital programs and the venture capital enterprises within a certain range, as the piloting of a transitional period. We can use 26 securities trading centers (including automatic quotation system) of China to carry out non-public listing, so that the stocks of some venture capital enterprises are liquid. That can not only withdraw partial venture capital, but also prepare for the establishment of the second-board market in the future. To list the stocks of the venture capital enterprises trained in the OTC market can reduce the risks for such enterprises to be directly listed in the second-board market.

Now China is establishing similar property right trading centers. Trough the trading centers, the investors can fully or partially purchase the property right or the equity of the venture enterprises, to obtain their ownership or the status of the shareholders, and the venture enterprises get capital to develop their new technologies. Early in May 2000, Beijing put forward Zhongguancun Technology Exchange Center. The functions of the center are to provide technologies, capital and the information of the supplier and the buyer, release the government procurement and scientific and technological tendering information, and carry out technology and property right trading. The center is a market platform which offers information service for the connection of technology holders and capital holders, so as to create a channel for the venture capital through the property right trading of hi-tech enterprises.

\subsection{Bankruptcy liquidation fully}

In addition, I notice that, among the researched 90 venture capital experts, no one choose to withdraw the investment through bankruptcy liquidation. Of course, no one is willing to go bankrupt. But the basic characteristics of the venture capital are high risk and high return. High return is for overall and individual programs, and high risk means the investment failures of most programs. According to the statistics, about $20 \%$ to $30 \%$ of America's venture capital programs are totally failed 60\% experience varying degrees of frustration, and only $5 \%$ to $10 \%$ programs are successful (FAN, SHEN \& CHEN, 1999). Failed programs and some frustrated programs can only withdraw the venture capital through liquidation. It shows that the time for the venture capital companies of China to engage in the venture capital business is very short, and the experts lack of knowledge of the characteristics of the "high risk" of the venture capital. Furthermore, China lacks correspondingly laws and 
regulations on the liquidation bankruptcy of the venture enterprises, and the bankruptcy procedures of other enterprises applicable to the Civil Procedure Law are obviously not conductive to the development of the venture capital industry. Without venture capital, the industrialization of scientific and technological achievements and the development of medium-sized and small-sized venture enterprises are difficult. And without a sound and complete withdrawal channel, the venture capital is not promising. We can refer to the foreign advanced experience and select the venture capital withdrawal approach, just after analyzing the domestic system, legal and human environments. Currently, China's capital market, property right trading market, venture capital system, legal and system conditions are not complete, so some venture capital withdrawal approaches which are quite successfully adopted abroad are difficult to be achieved in China for the time being. Therefore, to establish a sound venture capital withdrawal mechanism of China cannot be completed overnight, but we must not rush.

Therefore, I think in such a special transition period, we can take some expedient measures to promote the development of the venture capital industry of China. The most feasible way is to first use the withdrawal approaches like "shell" resources, OTC and overseas listing, so that the venture capital industry will not remain stagnant because of the lack of the withdrawal mechanism. Meanwhile, we must see the defects and gaps of the internal operation mechanism of venture capital of China and the external environment, and keep creating conditions in talent, science and technology, social economy, laws, etc., gradually remove the obstacles, and promote the improvement of the withdrawal mechanism, for example, provide more relaxed and feasible legal, financial and accounting, tax and other policy environments, attract capital from many approaches and aspects and enter the venture capital market, establish the capital organization form meeting the legal and investment habits, improve the agency service institution system, including industry self-regulatory organizations, scientific and technological program evaluation agencies, technology brokerage agencies, venture capital consulting bodies, legal and accounting service agencies, etc., train adventurous innovation spirit, honest business credit environment and the human environment respecting personal value, right and interest. Once the conditions in all respects are mature, we shall lose no time in establishing the multi-level and multi-channel venture capital withdrawal mechanism, e.g., open up the second-board market, so that the venture capital can gain investment profit through wider and smoother approaches, and realize the joint development with the capital market and science and technology.

\section{Conclusion}

In summary, venture capital is an investment method which is popular worldwide. By analyzing the whole operation process of venture capital, we are clear that, the key for the venture capital to produce circulatory profit is the withdrawal mechanism of venture capital. Therefore, the venture withdrawal mechanism has a very important significance. Successful withdrawal not only means high return, but also is the basis for a new round of venture capital. In establishing the venture capital withdrawal mechanism of China, we must refer to the foreign experience, in particular the America's successful experience. The main experience for America to be succeeded in venture capital lies in that its developed multi-level capital market and property market provide a multi-channel withdrawal method. America's withdrawal methods are classified into three types, i.e., public listing, sale and asset liquidation.

While referring to the foreign experience, we must establish the withdrawal mode relying on the national situations and restraining conditions of China and change it indirectly according to the realistic situations, i.e., IPO, such an internationally recognized gold withdrawal method, from the main-board market, the main-board market has too high an assess threshold. From the second-board market, the author believes that it is not realistic for the 
current China to realize venture capital through the second-board market. Nevertheless, IPO is not bad in the current realistic conditions of China, i.e., utilize the "shell" resource and overseas listing etc. Moreover, the sale method has many advantages, and the execution of the sale method in China still has a lot of obstacles. Now China is establishing similar property right trading centers. Through the trading centers, the investors can fully or partially purchase the property right or the equity of the venture enterprises, to obtain their ownership or the status of the shareholders, and the venture enterprises get capital to develop their new technologies. In addition, bankruptcy liquidation, China lacks correspondingly laws and regulations on the liquidation bankruptcy of the venture enterprises, and the bankruptcy procedures of other enterprises applicable to the Civil Procedure Law are obviously not conductive to the development of the venture capital industry.

So, some venture capital withdrawal approaches which are quite successfully adopted abroad are difficult to be achieved in China for the time being. So, in such a special transition period, we can take some expedient measures to promote the development of the venture capital industry of China. The most feasible way is to first use the withdrawal approaches like "shell" resources, OTC and overseas listing etc. Once the conditions in all respects are mature, there will be no time left in establishing the multi-level and multi-channel venture capital withdrawal mechanism, and realizing the joint development with the capital market and science and technology.

\section{References:}

CHENG, S. W.. (1999). Actively and steadily promote China’s venture capital career. Management World, 1.

CHENG, S. W., et al. (2000). Venture capital in China (1st ed.). Beijing: National Press.

FAN, B., SHEN, R. F. \& CHEN, D. M.. (2009). Research on China venture capital withdrawal mechanism and related legal system. Retrieved September 15, 2009 from http://www.drcnet.com.cn/DRCNET.Channel.Web/.

LIU, S. B.. (1999). Venture capital (1st ed.). Guangzhou: Guangdong Economic Press.

WANG, J. B.. (2008). Survey shows: Non-governmental fund accounts for a larger part in venture capital. Retrieved July 3 , 2008 from http://www.drcnet.com.cn/DRCNET.Channel.Web/.

(Edited by Ruby and Chris)

\section{(continued from Page 28)}

Saunders, J. \& Wong, V.. (1985). In search of excellence in the U.K. Journal of Marketing Management, 1 (Winter), 119-137.

Schlegmilch, B. B., Boyle, K. M . \& Therivel, S.. (1985). Marketing research in medium sized engineering companies in Britain and the United States-Some preliminary findings. Edinburgh University, Working paper series No. 85/16.

Shaw, V.. (1995). Successful marketing strategies: A study of British and German companies in the machine tool industry. Industrial Marketing Management, 24(4), 329-339.

Siu, W. S.. (2000). Marketing and company performance of Chinese small firms in Hong Kong. Marketing Intelligence \& Planning 18(5), 292-230.

Siu, W. S., Fang, W. \& Lin, T.. (2004). Strategic marketing practices and the performance of Chinese small and medium-sized enterprises (SMEs) in Taiwan. Entrepreneurship \& Regional Development, 16(2), 161-178.

Siu, W. S. \& Liu, Z.. (2005). Marketing in Chinese small and medium enterprises (SMEs): The state of the art in a Chinese socialist economy. Small Business Economics, 25, 333-346.

Thomas, M. J.. (2002). Editorial. Marketing Intelligence \& Planning, 20(7), 393.

Walker, O. C., Mullins, J. W., Boyd, H. W. \& Larréché, J. C.. (2006). Marketing strategy. New York: McGraw-Hill Irwin.

Wang, X. \& Yin, P.. (2005, November 11). More efforts needed for firms to go global. China Daily, (7).

Zhao, X. S., Tong, C. S. P. \& Qiao, J.. (2002). China's WTO accession, state enterprise reform, and spatial economic restructuring. Journal of International Development, 14(4), 413-433.

(Edited by Ruby and Chris) 